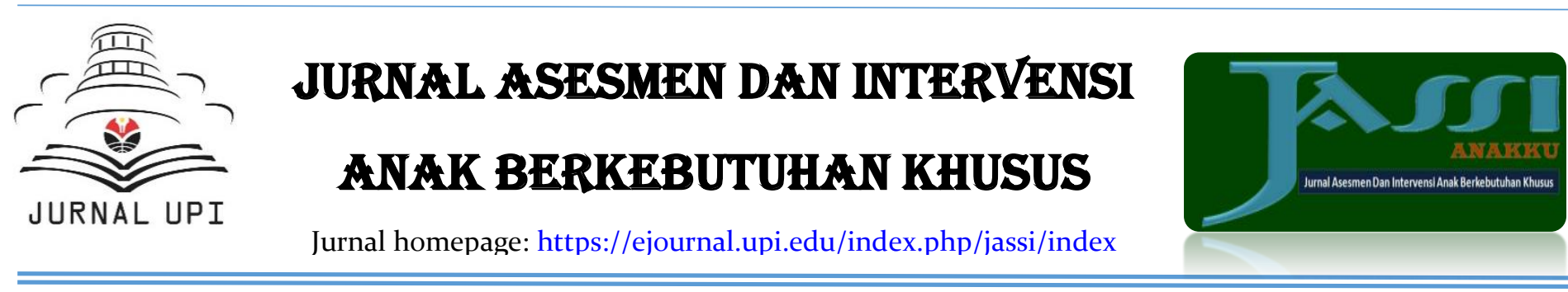

\title{
The Utilization of the Montessori Method in Improving the Ability of Clothes Buttoning Up for Student with Physical Impairment
}

\author{
Mamah Suryamah* \\ Special Needs School PUSPPA Suryakanti, Indonesia \\ *Correspondence: E-mail: suryamahmamah69@gmail.com
}

\section{A B S T R ACTS}

The purpose of this study is to explore the utilization of the Montessori method to improve the motor skill of students with physical impairment by practicing buttoning up the clothes using the clothing frame as a media of Montessori. Classroom action research was used as the method in this study. The subject of this study was two eight-year-old elementary students with physical impairment. The result of this study showed the students' improvement in buttoning up clothes through the media (a clothes frame with 5 buttons on it). The learning result of the second-grade students after interacting with the media through the Montessori method approach showed as $100 \%$ and $92.6 \%$. With the score of student activity $100 \%$ and $86,6 \%$. For cycle II, the performance test showed $100 \%$ and $97.33 \%$, both students got $100 \%$ in student activity test. The highest score of the cycle I was $100 \%$ and the lowest score was $86,6 \%$. The highest score of cycle II was 100 and the lowest was $97.33 \%$. Judging from the categorization of learning outcomes, cycle I and cycle II were in the very good category or perfect score. The data obtained indicate that the use of the Montessori approach can improve students' ability to perform buttoning up activities by themselves through using clothes frames with buttons.

\author{
ARTICLE INFO \\ Article History: \\ Received 30 Mar 2021 \\ Revised 30 Apr 2021 \\ Accepted 01 Mei 2021 \\ Available online 03 Mei 2021
}

\section{Keyword:}

Improving the ability to button clothes,

Montessori method,

Physical impairment. 


\section{INTRODUCTION}

Students with physical impairment experience difficulties when performing physical movements, behavior, or body shape, and impaired coordination of impaired students causes them to experience difficulties in carrying out their daily activities independently. For physical impairment students, the ability to take care of themselves or help themselves is an important ability that must be learned. Therefore, to provide a suitable learning method for students with physical impairment, the learning program must be given programmatically, simply, systematic, and specific, the program also needs to be given continuously so that students can acquire new skills and abilities that can be implemented in daily activities. One of the learning programs that must be taught to students with physical impairment is how to dress. There were several movement skills that students must do while dressing themselves, it is including inserting the sleeves, attaching the buttons (buttoning up the clothes), opening up the buttons (unbuttoning the clothes), and tidying them up. Students with physical impairment faced difficulties while dressing process, whether it is the process of inserting the sleeves, buttoning up the clothes buttons, and unbuttoning the clothes buttons. Based on this, to help students button up and unbutton the clothes buttons, it is necessary to do movement coordination exercises. The exercise must be carried out continuously through various approaches that can be implemented by students. One of the approaches that can be done to help students in the practice of button-up and unbuttoning the clothes buttons is through the Montessori approach.

Montessori stated that teaching children the values of independence can be done through practical daily activities so that children gain the freedom to do what they need. They can do the things they need to survive such as preparing food, attaching buttons, tying shoes, washing hands, etc. they can learn, acquire knowledge of life skills according to their stage of development. In this way, children can also feel happy and not feel forced (Hiles, 2018). Activity of the Montessori method is so specific that it contains the detail of every activity in daily life into a series of learning implementation plans including the development of life skills areas (Exercise Practical Life) which are divided into four specific areas, namely (1) basic motion exercises and activities for learning preparation; (2) Practice taking care of themselves ; (3) Exercises to take care for the environment; (4) Exercises for developing social skills, etiquette, and politeness (Cossentino, 2015). Furthermore, montessori teaching aids are types of teaching aids that have been used in various countries around the world. Maria Montessori is an Italian educator who introduced Montessori teaching aids. basic concepts of science, observation of children, and pedagogy are parts of Montessori educational methods (Susiaty et al., 2021). The Montessori method is quite effective for use in early childhood learning because it can develop children's social skills.

The Montesori approach emphasizes the activities of students by using concrete objects directly, this method approach makes students easier to understand the material presented because students are directly involved in these activities. This study discusses the use of the Montessori method in increasing the ability to button up and unbutton the clothes for students with physical impairment by using a clothing frame material with buttons. The clothes frame with buttons is a frame made of wood in a rectangular shape, on the left and right, the cloth is attached, the left side of the cloth has a buttonhole and the right side of the cloth is attached with buttons (Figure 1). The direct purpose of the exercise using a cloth frame with buttons was conducted so that students can button up and unbutton their clothes correctly, the indirect goal is for students to have discipline, independence, concentration, accuracy, endurance, patience, bilateral coordination, wrist rotation, and hand movements. 
and mathematical concepts (Geometric shapes). and the final goal is for students to be able to button their clothes or be able to wear their clothes. According to the results of this study, students' activities in buttoning up and unbuttoning buttons on the teaching media (clothes frames with buttons) had increased after learning was delivered using the Montessori approach. From these data, it is obtained that the use of the Montessori approach can increase the ability to button up and unbutton the clothes frame with buttons. Learning to open and close clothes frames with buttons through the Montesori approach is very effective for students with physical impairment because it makes it students easier to train their motor movements.

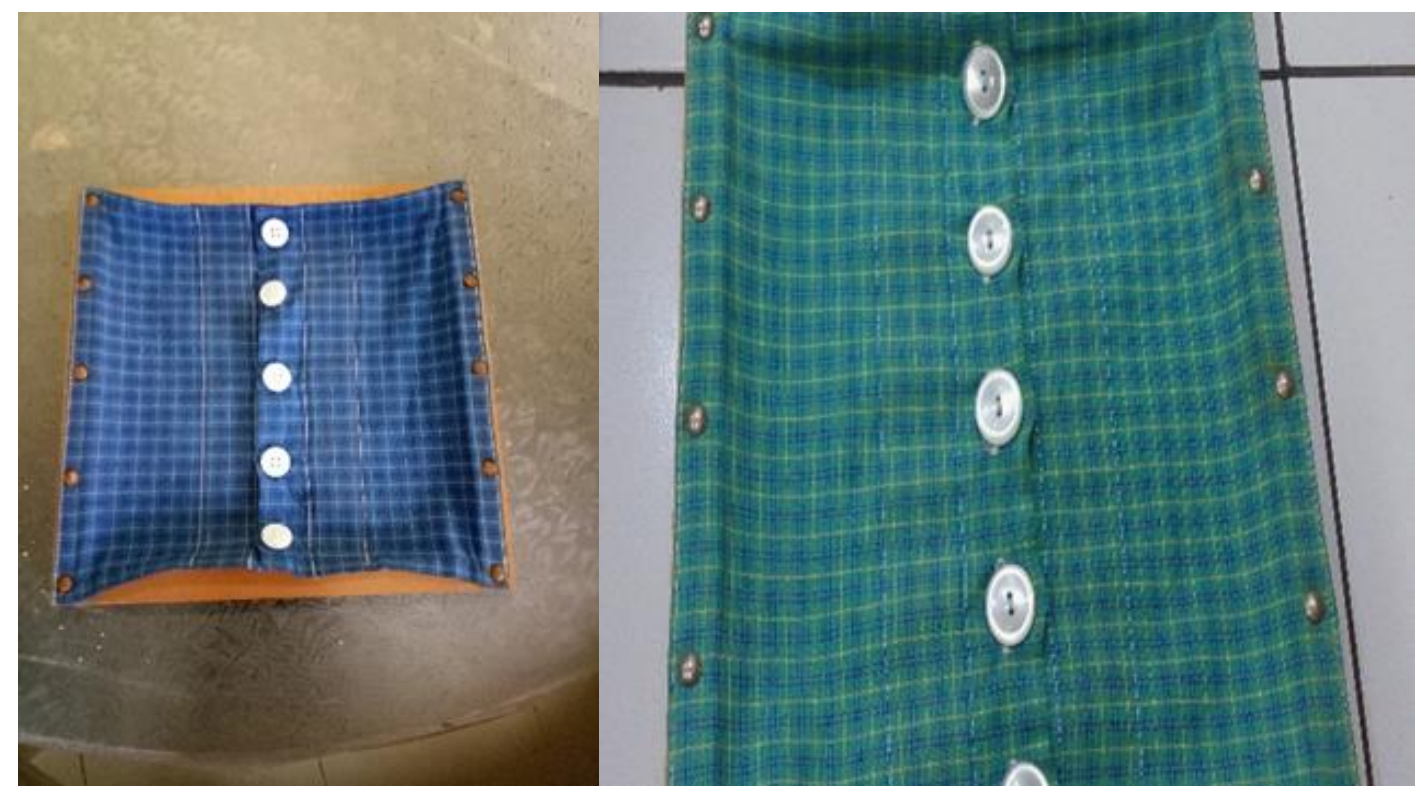

Figure 1. Clothes frame with buttons

\section{METHODS}

This type of research is classroom action research which aims to overcome learning problems in the classroom. According to Rahman and Haryanto (2014), classroom action research is conducted when a group of students is identified with the problem, then the researcher determines an action to overcome it. During the action, the researcher observes changes in behavior and the factors that cause the actions taken to be unsatisfactory, so the second action will be tried again and so on until it is successful (Rahman \& Haryanto, 2014).

\subsection{Research subject}

The research subjects were two students with disabilities with cerebral palsy type II elementary school at SLB Pusppa Suryakanti, Bandung City.

\subsection{Research procedure}

This research explores the Montessori method in improving the ability to button up the clothes in students with physical impairment, by focusing on the practice of buttoning up and unbuttoning the clothes frame with buttons. The flow used in this research consisted of four stages, namely: planning, action, observing, and reflecting. This research was conducted using two cycles (Figure 2). 


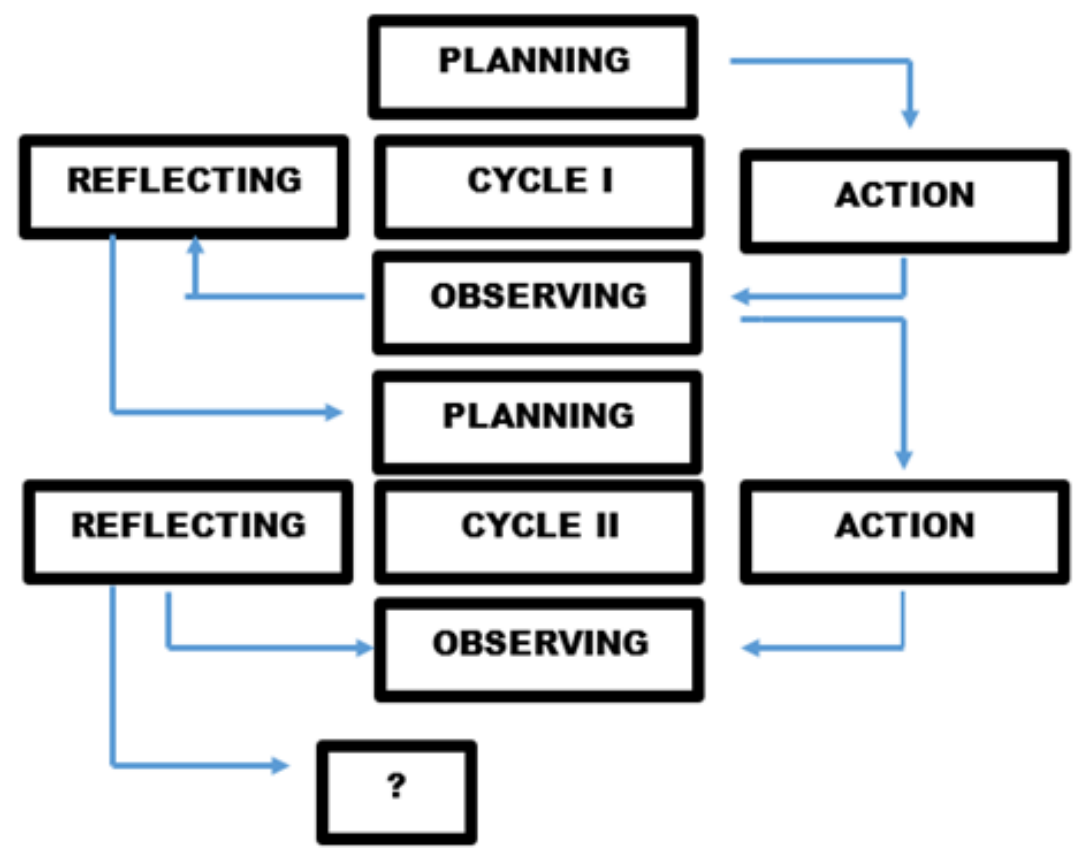

Figure 2. Schematic of research design.

\subsection{Activity procedure}

Figure 3 demonstrates the procedure for classroom action research activities, which consisted of stages of planning, implementation, observation, and reflection. In the action planning stage, the teacher does prepare the lesson plans, after that prepares task analysis observation sheets. In the implementation stage of doing individual learning, learning cannot be done classically because the learning requires special attention from the teacher to the students. In the observation stage, observing the activities of students through observation sheets. The reflection stage is an activity to evaluate the process, the results of the reflection are a combination of the results of the pre-test, the results of observations, and the results of the post-test. From the results of the reflection of the first cycle then plan the second cycle, so that the results achieved in the next cycle are as expected and should be better than the previous results.

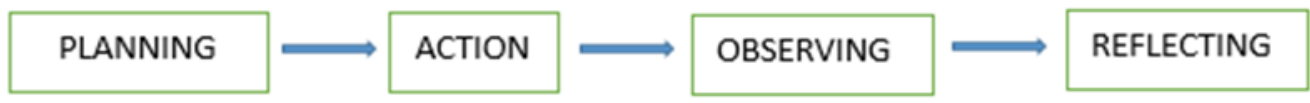

Figure 3. Procedure for classroom action research activities

\subsection{Research instrument}

The instruments employed in this study are (i) Learning outcomes tests were given at the end of each cycle, in the form of performance tests, and (ii) Student observation sheet in the form of task analysis

Research data were collected and compiled through data collection techniques which include:

(i) The collection of data obtained from the results of the Pre-test was conducted before taking action. The score of learning outcomes was obtained from calculating the total score of all the items tested. The assessment criteria were: 3 when the student was able to do it alone with the correct position, 2 when the student was able to do it alone even 
though the position was not correct, 1 when the student was able to do it with help, 0 when the student was unable to do it.

(ii) The collection of data obtained from the results of the Post-test.

(iii) Data collection obtained from the results of student observations. The assessment criteria were in the following: 3 when the student was able to do according to the task analysis, the value of 2 when the student was able to do the task not in accordance with the task analysis, the value of 1 when the student was able to do it with help, the value of 0 the student was unable to do the task.

Data collection was obtained from the results of the pre-test, post-test, and observation. From the data collection activities then continue to the data analysis to determine the value of student learning outcomes. Data analysis to determine the value of student learning outcomes in this study used a standardized value of 100 , using the following formula:

$$
\text { Value }=\frac{\text { Total score obtained by students }}{\text { Maximum score }} \times 100
$$

Furthermore, the results of the observation assessment are described as follows:

Assessment criteria

$\begin{array}{ll}\text { Very Good } & : 90 \%-100 \% \\ \text { Good } & : 70 \%-80 \% \\ \text { Enough } & : 55 \%-69 \% \\ \text { Less } & :<54 \%\end{array}$

\section{RESULTS AND DISCUSSION}

\subsection{Student demographics}

The results of the identification that have been carried out on children with physical impairment become the basis for providing further services. Assessment of Children with physical impairment is a systematic or regular and comprehensive or comprehensive process in exploring further problems to find out what are the problems, obstacles, strengths, and individual needs (Li et al., 2016).

Table 1 shows student demographic consists of motor skills, communication skills, concentration skills, language skills, and academic skills. FHZ has poor motor skill, and communicate in an unclear language, in language skill, he is only able to say simple words, he has good concentration, and has good academic skill. SAL has poor motor skills, can communicate with a gesture, he acquired new language skills to say yes and no, he does not have a good concentration, must be reminded oftentimes, his academic abilities not that good. Table 2 show student ability conditions and Figure 4 show student demographic.

Table 1. Students Condition

\begin{tabular}{cccll}
\hline No & Stundent's Name & Age & State of the Subject & Notes \\
\hline 1 & FHZ & 8 years- old & $\begin{array}{l}\text { Has poor motor skills, can communicate } \\
\text { in unclear language, is only able to say eager to learn } \\
\text { simple words, has good concentration, } \\
\text { has good academic skills }\end{array}$ \\
& SAL 8 years- old & $\begin{array}{l}\text { Has poor motor skills, can communicate Energetic and } \\
\text { with gestures and can say yes and no eager to learn } \\
\text { only, does not have good concentration, } \\
\text { must be reminded often, not that good } \\
\text { in academic skill. }\end{array}$ & \\
\hline
\end{tabular}


Table 2. Student Ability Conditions

\begin{tabular}{clccccc}
\hline No & Name & Motor Skil & Comuni-Cation & Concentra-Tion & Language & Academic \\
\hline 1 & FH & 3 & 2 & 3 & 2 & 3 \\
2 & SAL & 2 & 1 & 2 & 1 & 1 \\
\hline
\end{tabular}

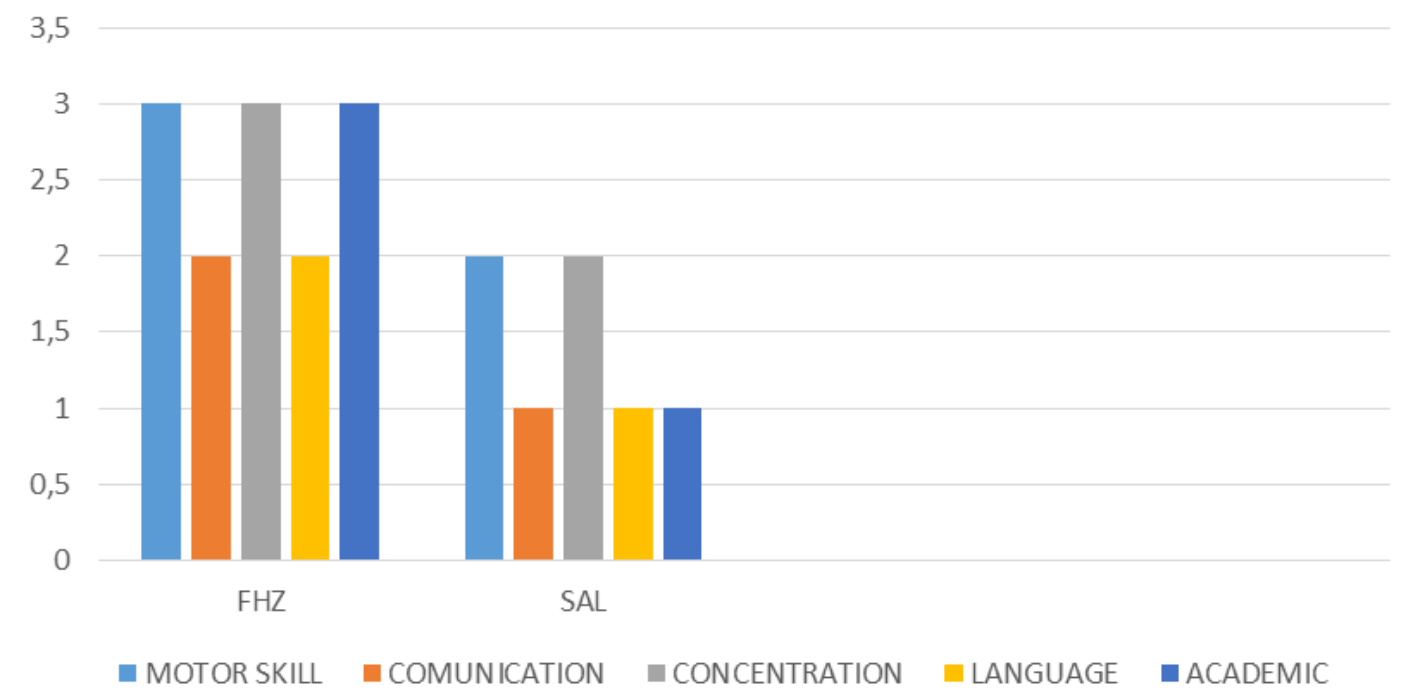

Figure 4. Student Demographic

\subsection{Learning Process Activities}

The learning activities in Cycle I and Cycle II have different learning materials, Cycle I learns about unbuttoning the clothing frames with buttons (Figure 1.), Cycle II learns about buttoning up the clothing frames with buttons.

The first cycle of learning is the initial activity (10 minutes) the teacher and students prepare the lesson, the class is opened by praying together, the teacher and students have interactive conversations, the teacher checks the students' attendance. Core activity (65 minutes), Students watch a video about the practice of unbuttoning on a clothing frame with buttons, students observe a clothing frame with buttons, the teacher explains that today we will learn about practicing unbuttoning the buttons on the clothes frame, the teacher explained how to unbutton the buttons. on the clothes frame, students pay attention to the teacher's explanation about how to unbutton the clothes frame, students started trying to unbutton the clothes frame, students observe the buttons on the clothes frame and try to unbutton it, students try to practice how to unbutton the buttons on the clothes frame, students can open the buttons on the clothing frame. Final Activity (15) students and teachers reflect on the learning that had been done, students and teachers concluded the learning outcomes, students store clothes frames with buttons in the storage.

Cycle II learning is the initial activity (10 minutes) the teacher and students prepare the lesson, the class is opened by praying together, the teacher and students had interactive conversations, the teacher checked the students' attendance. Core activity (65 minutes), Students watch a video about how to button up the buttons on the clothes frame with buttons, students observe the clothes frame with buttons, the teacher explained the activity about practicing buttoning up the buttons on the clothes frame, the teacher explained how to button up the buttons on the clothes frame, students paid attention to the teacher's 
explanation about how to button up the buttons on the clothes frame, students started to button up the buttons on the clothes frame, students showed how to button up the buttons on the clothes frame. Students observed the buttons on the clothes frame and try to attach them, students try to practice how to button up the buttons on the clothes frame, and students can close the buttons on the clothes frame. Final Activity (15) students and teachers reflect on the learning activity that had been done in place, students and teachers conclude the learning outcomes, students store clothes frames with buttons in the storage.

\subsection{Pre-test results, post-test results, and results of each cycle or learning outcomes}

From the results of the table 3 , it can be seen that the initial conditions of students before using the Montessori approach were low. After being given action by using the method of the Montessori approach in cycle I, the student's ability had increased and if it was presented as a whole the score for $\mathrm{FHZ}$ was $100 \%$, and the SAL value was $92.06 \%$. Then in cycle II, the results increased with a very good value and if it was presented the $\mathrm{FHZ}$ value was $100 \%$ and the SAL value was $97.33 \%$. Figure 5 show performance test result.

Table 3. Illustrates the increase in performance test results

\begin{tabular}{ccccccc}
\hline No & Name & Pre-test & $\begin{array}{c}\text { Post- test } \\
\text { Cycle i }\end{array}$ & $\begin{array}{c}\text { Post-test } \\
\text { Cycle ii }\end{array}$ & $\begin{array}{c}\text { Escalation from } \\
\text { pre-test to cycle i }\end{array}$ & $\begin{array}{c}\text { Escalation from } \\
\text { pre-test to cycle ii }\end{array}$ \\
\hline 1 & FHZ & $40.0 \%$ & $100.0 \%$ & $100.0 \%$ & $60.0 \%$ & $60.0 \%$ \\
2 & SAL & $6.3 \%$ & $92.6 \%$ & $97.3 \%$ & $86.3 \%$ & $91.0 \%$ \\
\hline
\end{tabular}

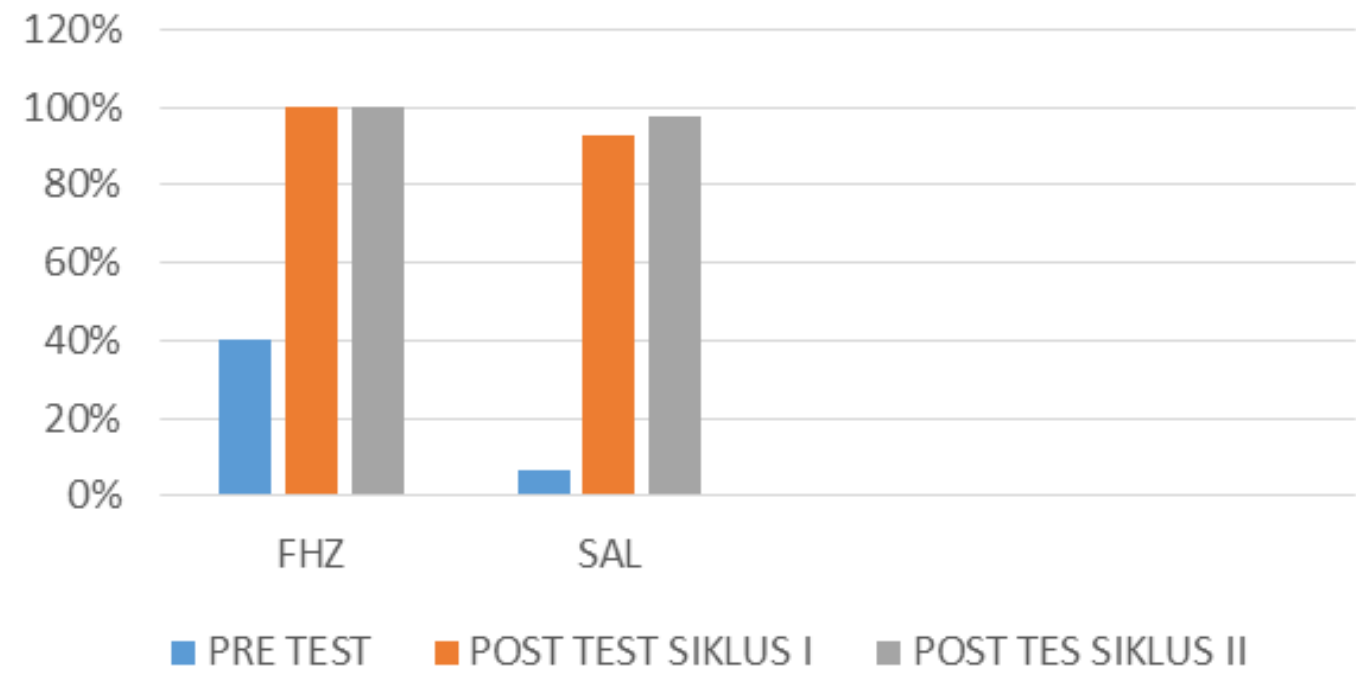

Figure 5. Performance test results.

From the results of the table 4, it can be seen that the ability of students in task analysis was still low. After the Montessori approach was implemented, the students' abilities increased and it was in the range of very good and good scores. Figure 5 show results of student activity data. 
Table 4. Describes the escalation in student activity data results after the actions of Cycle I and Cycle II

\begin{tabular}{llccccc}
\hline \multirow{2}{*}{ No } & Student & \multicolumn{2}{c}{ The Object That Was Observed } & \multirow{2}{\text{Escalation}}{\begin{tabular}{c} 
Escalation From \\
From Pre-Test \\
\cline { 3 - 4 }
\end{tabular}} & \multicolumn{3}{c}{ Task Analysis } & $\begin{array}{c}\text { Pre-Test To } \\
\text { Cycle li }\end{array}$ \\
\cline { 2 - 4 } & Pretest & Cycle i & Cycle ii & To Cycle I & $60 \%$ \\
\hline 1. & FHZ & $40 \%$ & $100 \%$ & $100 \%$ & $60 \%$ & $73,4 \%$ \\
2 & SAL & $26,6 \%$ & $86,6 \%$ & $100 \%$ & $60 \%$ & \\
\hline
\end{tabular}

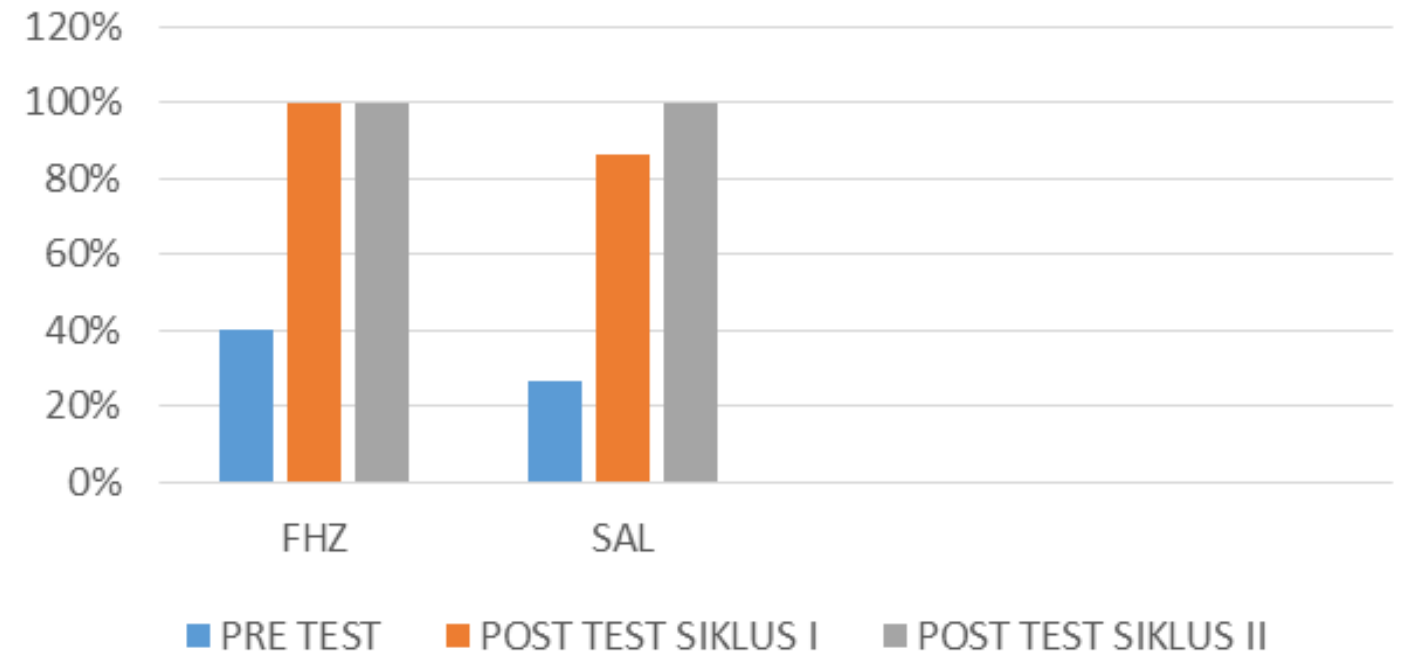

Figure 5. Results of student activity data

\subsection{Analysis of the results of research activities}

The results obtained showed an increase in the ability to unbutton and button up the buttons on the clothes frame with buttons. This statement is supported by the results of descriptive data analysis which can be seen in the table. The learning outcomes of grade II students after using a button clothing frame using the Montessori approach were as follows: the performance test in the first cycle was $100 \%$ and $92.6 \%$. student activity scores were $100 \%$ and $86.6 \%$. For the second cycle of the performance test, the score was $100 \%$ and $97,33 \%$, the student activity was $100 \%$. The highest value in the first cycle is 100 and the lowest value is $86.6 \%$. The highest value in the second cycle is 100 and the lowest value is $97.33 \%$. Judging from the category of learning outcomes, cycle I and cycle II are in the very good category or perfect score.

The activity of students in unbuttoning and buttoning up the buttons on the clothes frame with buttons increased after learning was given using the Montessori approach. From this data, it found that by using the Montessori approach the ability to open and close the clothes frame with buttons increases the students' ability to unbutton and button up their clothes independently. 


\section{CONCLUSION}

Based on the results of the research, data analysis, and discussion, it can be concluded that learning to unbutton and button up the clothes frame with buttons through the Montessori approach for students with physical impairment can increase their motor skills. Based on the results of the research, data analysis, and discussion, it can be concluded that learning to unbutton and button up the clothes frame with buttons through the Montessori approach for students with physical impairment can increase their motor skills. Considering that the results obtained in this classroom action research are very positive, some suggestions can be made as follows:

(i) Learning for students can be given using the Montessori approach.

(ii) Learning media can foster students' interest and motivation in learning and can clarify students' understanding of learning materials.

(iii) The Montessori approach is effective in helping students with disabilities understand learning approach in helping students with disabilities understand learning.

\section{ACKNOWLEDGMENT}

We acknowledged"SLB Pusppa Suryakanti". This Study was supported by Kantor Jurnal dan Publikasi (KJP)-Universitas Pendidikan Indonesia (UPI), Departemen Pendidikan Khusus-UPI, dan Dinas Pendidikan Provinsi Jawa Barat bidang Pendidikan Khusus (PKLK). We also thank to Rifa F Darmawan and Diana Evrilliawati. We also acknowledge Deden Syaiful Hidayat, M.Pd. (Kepala Bidang PKLK), Dr.Eng.asep Bayu dani Nandiyanto (Kepala Kantor, KJP UPI), Dr.Yuyus Suherman (Ketua Departemen, Departemen Pendidikan Khusus, UPIO, Rina Maryanti, M.Pd (assistant Profesor, Departemen Pendidikan Tata Boga, UPI, Ahmad Bukhori Muslim (Director, Directorate of International Affairs, UPI), Nissa Nur Azizah, Dwi Fitria Al Husaeni. This program is also supported by Program Pengabdian Masyarakat ang Bangdos UPI.

\section{AUTHORS' NOTE}

The authors declare that there is no conflict of interest regarding the publication of this article. The authors confirmed that the paper was free of plagiarism.

\section{REFERENCES}

Cossentino, J. (2005). Ritualizing expertise: A non-Montessorian view of the Montessori method. American Journal of Education, 111(2), 211-244.

Hiles, E. (2018). Parents' reasons for sending their child to Montessori schools. Journal of Montessori Research, 4(1), 1-13.

Li, R., Sit, C. H., Jane, J. Y., Duan, J. Z., Fan, T. C., McKenzie, T. L., and Wong, S. H. (2016). Correlates of physical activity in children and adolescents with physical disabilities: A systematic review. Preventive Medicine, 89, 184-193.

Rahman, B., and Haryanto, H. (2014). Peningkatan keterampilan membaca permulaan melalui media flashcard pada siswa kelas I SDN Bajayau Tengah 2. Jurnal Prima Edukasia, 2(2), 127-137. 
Susiaty, U. D., Firdaus, M., and Andriati, N. (2021). Pengembangan Alat Peraga Papan Positif Negatif Berbasis Metode Montessori pada Siswa dengan ADHD. Mosharafa: Jurnal Pendidikan Matematika, 10(1), 73-84. 